\title{
Pengembangan Media Pembelajaran Digital Berbasis Augmented Reality pada Topik Klasifikasi Hewan Berdasarkan Habitatnya
}

\author{
Yeni Nurhasanah, Daniah Adjani Putri \\ Jurusan Desain, \\ Politeknik Negeri Media Kreatif \\ Jalan Srengseng Sawah, Jagakarsa, Jakarta Selatan, +62-21-7864753/55 \\ nurhasanah_yeni@polimedia.ac.id, daniah0103@gmail.com
}

Diterima : 28 Mei 2020. Disetujui : 7 Agustus 2020. Dipublikasikan : 3 Oktober 2020.

\begin{abstract}
Augmented Reality as one of the developing fields in the Industrial Age 4.0 has been widely used in various fields. Augmented Reality (AR) can be used to deliver the information that may be very difficult to do directly in the real world. Many fields use Augmented Reality based media to deliver the information to their target users. Augmented Reality has been developed to help the learning process become more fun and interactive. The learning process aims to provide experience and share information and knowledge in an interesting and meaningful way for students. The process that was previously impossible for students can be helped by using Augmented Reality-based learning media. One of them is in learning science in elementary schools on the topic of animal recognition based on their habitat. Through this digital learning media based on Augmented Reality, students can see how the physical shape of the animals in question is 3D by using an Android device. Augmented Realitybased digital learning media created using Unity 3D and Vuforia. This application is capable of displaying 3D models also able to present a video explanation of the $3 D$ model. In this project virtual buttons are also applied so that users are more challenged in using it.
\end{abstract}

Keywords: augmented reality, digital media, animals, android

Abstrak-- Augmented Reality sebagai salah satu bidang yang berkembang di Era Industri 4.0 sudah banyak digunakan dalam berbagai bidang. Augmented Reality (AR) dapat digunakan sebagai penyampai sebuah informasi yang mungkin sangat sulit untuk dilakukan secara langsung pada dunia nyata. Banyak bidang yang menggunakan media berbasis AR untuk menyampaikan informasi kepada target penggunanya. Augmented Reality banyak dikembangkan untuk membantu proses pembelajaran menjadi lebih menyenangkan dan interaktif. Proses pembelajaran bertujuan untuk memberikan pengalaman dan membagikan informasi dan ilmu pengetahuan secara menarik dan bermakna bagi para siswa. Proses yang tadinya tidak mungkin dialami oleh parasiswa dapat dibantu dengan menggunakan media berbasis Augmented Reality. Salah satunya dalam pembelajaran IPA di Sekolah Dasar pada topik pengenalan hewan berdasarkan habitatnya. Melalui media pembelajaran digital berbasis AR ini, siswa dapat melihat bagaimana bentuk fisik dari hewan yang dimaksud secara 3 Dimensi dengan menggunakan perangkat Android. Aplikasi AR yang dibangun dibuat dengan menggunakan Unity 3D dan Vuforia. Aplikasi ini mampu menampilkan model 3D juga mampu menyajikan video penjelasan model 3D tersebut. Dalam projek ini juga, diaplikasikan virtual button sehingga pengguna lebih tertantang dalam menggunakannya.

Kata kunci: augmented reality, media digital, hewan, android.

\section{PENDAHULUAN}

Klasifikasi hewan berdasarkan habitatnya merupakan salah satu pokok bahasan dalam kurikulum Ilmu Pengetahuan Alam pada jenjang Sekolah Dasar. Materi ini, pertama kali diajarkan di kelas empat SD semester 1, di mana pada masa ini anak anak sedang mengalamai tahapan operasional konkret. Anak yang berada pada Tahap operasional konkret masih membutuhkan bantuan media peraga yang dapat menjelaskan konsep abstrak yang mereka dapatkan. Pada tahap ini, anak sudah cukup matang untuk menggunakan pemikiran logika atau operasi, tetapi hanya untuk objek fisik yang ada saat ini. Dalam tahap ini, anak telah hilang kecenderungan 
terhadap animism dan articialisme. Egosentrisnya berkurang dan kemampuannya dalam tugas-tugas konservasi menjadi lebih baik. Namun, tanpa objek fisik di hadapan mereka, anak-anak pada tahap operasional kongkrit masih mengalami kesulitan besar dalam menyelesaikan tugas-tugas logika [1].

Augmented Reality sebagai salah satu bidang yang berkembang di Era Industri 4.0 sudah banyak digunakan dalam berbagai bidang kehidupan manusia. Augmented Reality (AR) merupakan teknologi yang dapat digunakan sebagai penyampai sebuah informasi yang mungkin sangat sulit untuk dilakukan secara langsung pada dunia nyata. Banyak bidang yang menggunakan media berbasis AR untuk menyampaikan informasi kepada target penggunanya. Augmented Reality bukan merupakan dunia virtual yang menggantikan dunia nyata tetapi menambahkan konten virtual ke dalam dunia nyata melalui perangkat digital secara real time. Augmented Reality dapat memvisualisasikan sesuatu yang mungkin sulit untuk diperoleh pengalamannya pada kenyataan.

Dalam dunia pendidikan, banyak penelitian yang dikembangkan berhubungan dengan pemanfaatan teknologi Augmented Reality pada pengenalan hewan. Diantaranya adalah aplikasi Augmented Reality untuk pendidikan science untuk membantu siswa memahami klasifikasi hewan berdasarkan jenis makanannya dan dapat digunakan sebagai multimedia pembelajaran alternatif tentang klasifikasi hewan. Hasil dari penelitian menunjukkan bahwa responden menilai bahwa aplikasi ini dapat membantu siswa memahami klasifikasi hewan berdasarkan makanannya dan dapat digunakan sebagai alternatif multimedia pembelajaran mengenai klasifikasi hewan [2]. Penelitian mengenai Implementasi Augmented Reality untuk mengenalkan hewan di kebun binatang menunjukkan hasil bahwa kombinasi informasi fisik dan virtual memberikan pengalaman yang menarik dan menyenangkan. Game yang dikembangkan pada penelitian ini bertujuan meningkatkan pengetahuan pengguna tentang hewan di kebun binatang. Target penelitian ini adalah anak anak dan penyandang disabilitas [3]. Penelitian selanjutnya adalah implementasi aplikasi Augmented Reality untuk pembelajaran tentang organisme akuatik pada pelajaran science menunjukkan hasil bahwa siswa memiliki motivasi dan konsentrasi yang lebih baik dengan penggunaan media pembelajaran berbasis Augmented Reality [4].

Berdasarkan pemaparan diatas, maka penulis bermaksud membuat media pembelajaran digital berbasis Augmented Reality sebagai upaya untuk membantu para guru dalam proses pembelajaran IPA pada materi klasifikasi hewan berdasarkan habitatnya. Aplikasi media pembelajaran digital ini menyajikan konten virtual berupa video, model 3D, dan virtual button yang digunakan untuk mengaktifkan video penjelasan dari hewan yang bersesuaian.

\section{TINJAUAN PUSTAKA}

\section{A. Tahap Perkembangan Intelektual Anak Usia 7-12 Tahun}

Menurut teori piaget, anak usia 7-12 tahun berada pada tahap operasional konkret. Pada tahap ini, anak dapat melakukan konservasi logika tentang kelas dan hubungan pengetahuan tentang angka berpikir terkait dengan yang nyata [5]. Pada tahap ini, anak sudah cukup matang untuk menggunakan pemikiran logika atau operasi, tetapi hanya untuk objek fisik yang ada saat ini. Dalam tahap ini, anak telah hilang kecenderungan terhadap animism dan articialisme. Egosentrisnya berkurang dan kemampuannya dalam tugas-tugas konservasi menjadi lebih baik. Namun, tanpa objek fisik di hadapan mereka, anak-anak pada tahap operasional kongkrit masih mengalami kesulitan besar dalam menyelesaikan tugas-tugas logika [1].

Salah satu hal yang menunjang perkembangan intelektual pada anak adalah pengalaman. Hal ini merupakan hal yang harus menjadi perhatian dan pegangan baik oleh orang tua ataupun para pendidik. Memberikan pengalaman belajar yang menarik merupakan tugas yang menantang bagi para orang tua dan pendidik. Dalam prinsip-prinsip perkembangan dinyatakan bahwa pembelajaran (learning-the activity of obtaining knowlege) berkontribusi pada perkembangan. Pembelajaran merujuk adanya pemahaman dan kemampuan yang meningkat. Dengan memanfaatkan pengalaman nyata, perkembangan kognitif seseorang akan lebih baik daripada hanya menggunakan bahasa untuk berkomunikasi. Berbahasa sangat penting untuk berkomunikasi. Namun, jika tidak diikuti oleh penerapan dan pengalaman maka perkembangan kognitif seseorang akan cenderung mengarah ke verbalisme (banyak menghafal) [6].

\section{B. Media Pembelajaran Digital}

Pembelajaran merupakan sebuah proses untuk memperoleh pengetahuan. Dalam proses ini dibutuhkan media untuk membantu kelancaran dan pengoptimalan proses tersebut. Dalam hal ini, Media adalah sebagai perantara yang digunakan untuk membantu kelancaran dan kesuksesan proses pembelajaran. Kata media menurut Kamus Besar 
Bahasa Indonesia memiliki beberapa arti diantaranya adalah alat, perantara, penghubung [7]. Gerlach dan Ely menjelaskan bahwa media apabila dipahami secara garis besar adalah manusia, materi, atau kejadian yang membangun kondisi sehingga membuat siswa mampu memperoleh pengatahuan, keterampilan, atau sikap. Dalam pengertian ini, guru, buku teks, dan lingkungan sekolah merupakan media.

Dalam proses belajar mengajar, secara lebih khusus media cenderung diartikan sebagai alat-alat grafis (bidang-bidang yang secara visual dapat menjelaskan hubungan yang ingin disajikan), photografis, atau elektronis untuk menangkap, memproses, dan menyusun kembali informasi visual atau verbal [8]. Sedangkan pembelajaran digital merupakan suatu sistem yang dapat memfasilitasi pembelajar belajar lebih luas, lebih banyak, dan bervariasi. Melalui fasilitas yang disediakan oleh sistem tersebut, pembelajar dapat belajar kapan dan dimana saja tanpa terbatas oleh jarak, ruang dan waktu. Materi pembelajaran yang dipelajari lebih bervariasi, tidak hanya dalam bentuk verbal, melainkan lebih bervariasi seperti teks, visual, audio, dan gerak [9]. Jadi, Media pembelajaran digital yang dimaksud pada penelitian ini adalah teknologi di era digital baik itu komputer, perangkat mobile, internet, video game ataupun perangkat lainnya yang digunakan sebagai alat untuk menyampaikan materi pembelajaran.

\section{Augmented Reality}

Augmented Reality (realitas berimbuh) merupakan teknologi yang menghadirkan konten virtual ke dalam dunia nyata. Konten virtual yang disajikan dapat berupa model 3D, Animasi 3D, maupun Video. Teknologi Augmented Reality merupakan teknologi interaksi yang sedang banyak dikembangkan di masa kini. Teknologi Augmented Reality sangat berguna dalam dunia pendidikan salah satunya dapat digunakan sebagai media pembelajaran yang menarik dan interaktif. Augmented Reality memungkinkan membawa perubahan yang inovatif dan signifikan pada dunia pendidikan yang sejalan dengan kebutuhan dan persyaratan dari para siswa atau peserta didik, para guru dan masyarakat pada saat ini dan masa depan [10].

Augmented Reality adalah menciptakan lapisan informasi digital di atas dunia fisik yang dilihat melalui perangkat Android atau Ios [11]. Augmented Reality adalah perluasan dari realitas virtual (VR). Scene dan objek yang ada disajikan secara virtual dalam aplikasi VR, sedangkan dalam aplikasi AR, informasi atau objek virtual disajikan dalam scene aktual setelah proses komputasi. Karakteristik dasar dari teknologi Augmented Reality diantaranya adalah pertama Objek virtual dkombinasikan dengan lingkungan nyata, kedua interaksi berjalan secara realtime, ketiga Augmented Reality berjalan pada lingkungan 3 Dimensi [4].

\section{Alur Pembuatan Aplikasi Media Pembelajaran Digital}

Pembuatan aplikasi media pembejalaran digital ini menggunakan metode Software Development Life Cycle (SDLC). SDLC adalah kumpulan dari berbagai langkah yang diikuti untuk pengembangan yang sistematis, desain, dan pemeliharaan proyek perangkat lunak dan memastikan bahwa semua kebutuhan pengguna dipenuhi dengan jumlah konsumsi sumber daya paling sedikit [12].

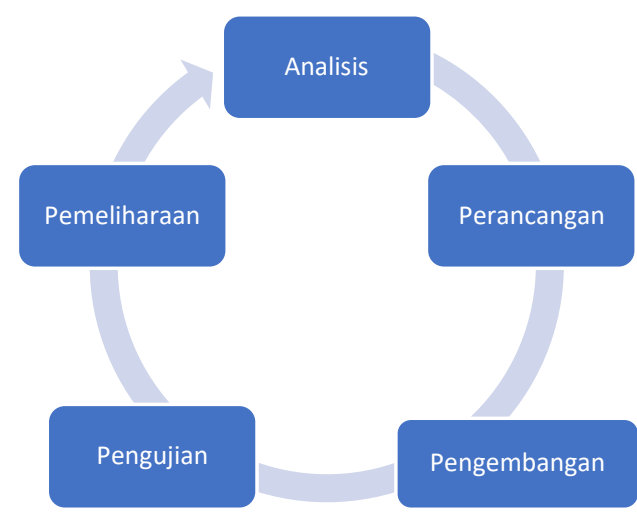

Gambar 1 Metode Pengembangan Aplikasi

Tahapan yang dilalui dalam pengembangan aplikasi dengan menggunakan metode Software Development Life Cyle adalah sebagai berikut:

1. Analisis

Pada tahap ini dilakukan pemilihan target user dan materi pembelajaran untuk pembuatan aplikasi. kemudian, dilakukan analisis kebutuhan sesuai dengan target user dan materi yang sudah dipilih. Pemilihan platform untuk deploy aplikasi media pembelajaran. Perencanaan testing dan pembuatan timeline penelitian.

2. Perancangan

Pada tahap ini dilakukan finalisasi spesifikasi aplikasi berdasarkan target user. Melakukan perancangan antar muka sistem. Finalisasi rancangan user interface. Pemilihan software yang digunakan untuk mengembangkan aplikasi.

3. Pengembangan

Tahap ini merupakan tahap implementasi pembuatan aplikasi. Pada tahap ini dilakukan pemrograman dengan menggunakan software 
atau engine yang sudah dipilih untuk merealisasikan dan membuat aplikasi sesuai dengan yang sudah dirumuskan pada tahap perencanaan dan perancangan

4. Pengujian

Pada tahap ini dilakukan verifikasi dan validasi terhadap aplikasi yang sudah dibuat. Apakah aplikasi yang sudah dibuat sudah berjalan sesuai dengan perancangan dan apakah fungsionalitas aplikasi sudah berjalan dengan baik. Pengujian dilakukan terhadap ahli materi dan ahli media.

5. Pemeliharaan

Pemeliharaan terhadap aplikasi yang sudah dibuat. Pada tahap ini dilakukan perbaikan apabila ada error atau kesalahan yang muncul ketika aplikasi digunakan. Selain itu, dilakukan juga penyesuaian atau adaptasi sesuai dengan kebutuhan.

\section{METODE PENELITIAN} berikut.

Metode penelitian dapat dijelaskan sebagai

\section{A. Analisis}

Produk yang dikembangkan harus bermanfaat dan merupakan solusi atas permasalahan yang terjadi di lapangan. Metode yang digunakan untuk menemukan permasalahan tersebut adalah dengan observasi lapangan dan studi literatur. Aktivitas pada tahapan ini meliputi:

1. Menemukan permasalahan

Kegiatan ini dilakukan untuk menemukan permasalahan yang membutuhkan solusi dengan menggunakan bantuan teknologi. Penulis menganalisis jurnal pendidikan IPA Sebelumnya untuk pengenalan hewan dan belum ada media pembelajaran digital berbasis Augmented Reality untuk pengenalan hewan berdasarkan habitatnya.

2. Studi literatur

Setelah menemukan permasalahan, langkah selanjutnya adalah melakukan studi literatur. Studi literatur ini, meliputi kajian terhadap standar kompetensi dan pemilihan kompetensi dasar mata pelajaran IPA di sekolah dasar. Pada penelitian ini dipilih topik pengenalan hewan berdasarkan habitatnya. Pengguna minimal berada di jenjang Sekolah Dasar kelas empat. Kemudian, menentukan landasan teori yang sesuai dengan teknologi yang digunakan untuk membuat media pembelajaran pada topik yang dipilih.
3. Analisis kebutuhan

Aktifitas ini dilakukan untuk mengetahui daftar kebutuhan yang harus diperhatikan dalam pengembangan media pembelajaran. Produk yang dikembangkan ini harus sesuai dengan kebutuhan target pengguna.

4. Pemilihan platform Aplikasi ini akan berjalan pada platform android.

B. Perancangan

Pada tahap ini kegiatan yang dilakukan adalah sebagai berikut:

1. Pemilihan software yang digunakan untuk pengembangan aplikasi. Pembuatan media pembelajaran berbasis AR ini akan menggunakan Unity 3D dan Vuforia.

\section{Game Engine Unity}

Unity3D adalah sistem pembuatan game lintas platform yang dikembangkan oleh Unity Technologies, dengan konten game engine dan sebuah lingkungan pengembangan terintegrasi (IDE) [13]. Game Engine Unity dapat digunakan untuk mengembangkan konten interaktif seperti video game, Augmented Reality, Virtual Reality dan Animasi 3D. Editor unity dapat berjalan pada Platform Window dan Mac OS X. Meskipun hanya berjalan pada 2 Sistem operasi tersebut tetapi Unity memiliki kemampuan untuk membangun aplikasi untuk digunakan secara multiplatform seperti untuk Windows, android, Windows phone dan lain lain.

\section{Vuforia SDK}

Vuforia Engine adalah platform perangkat lunak untuk membuat aplikasi Augmented Reality. Para Pengembang dapat dengan mudah menambahkan fungsionalitas visi komputer canggih ke aplikasi apapun. Hal tersebut memungkinkannya untuk mengenali gambar dan objek, dan berinteraksi dengan ruang di dunia nyata [14]. 


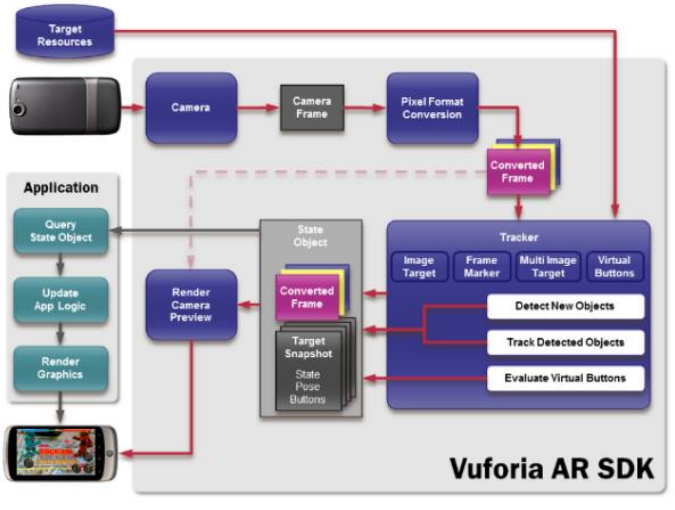

Gambar 2 Vuforia AR SDK

2. Finalisasi kebutuhan fungsional sistem.

Penelitian ini fokus pada pengembangan media pembelajaran digital pada mata pelajaran Science Kelas 4 SD berdasarkan Kurikulum 2013 [15]. Topik yang dipilih adalah klasifikasi hewan berdasarkan habitatnya. Sementara itu, kebutuhan fungsional sistem didefiniskan sebagai berikut:

a. Sistem menampilkan penjelasan melalui video audio mengenai klasifikasi hewan berdasarkan habitatnya secara menarik dan interaktif.

b. Sistem menampilkan objek 3D ataupun animasi 3D dari contoh hewan tertentu.

c. Sistem menggunakan virtual button untuk mengaktifkan video penjelasan pada menu scan animals

d. Media pembelajaran digital ini akan berjalan pada platform android minimal versi 4.2.

Skema umum fungsionalitas media pembelajaran digital ini dapat dilihat pada Gambar 3.

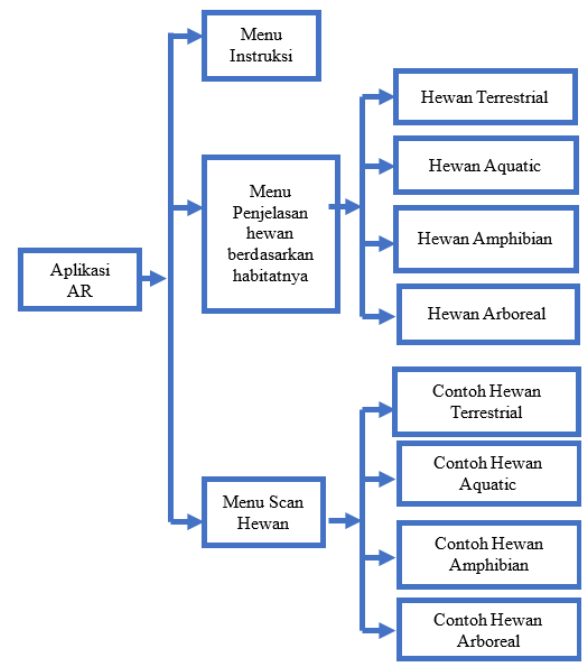

Gambar 3 Skema Umum Fungsionalitas Aplikasi

\section{Perancangan Antarmuka Sistem}

a. Menu Beranda

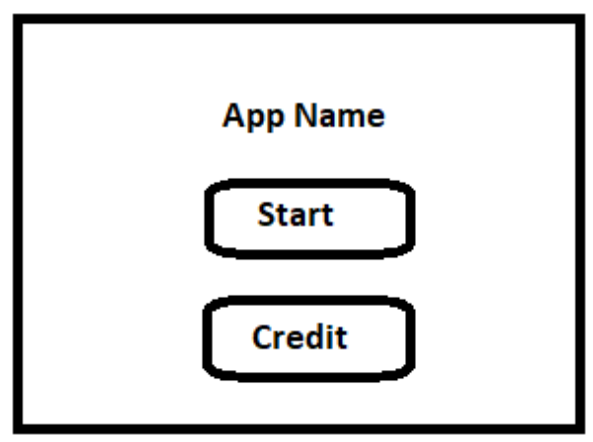

Gambar 4 Desain UI Menu Beranda

b. Menu Utama

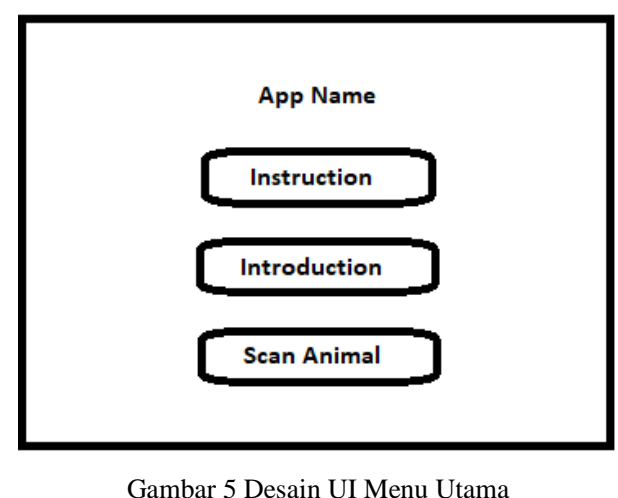

\section{Pengembangan}

Proses yang dilalui pada tahap ini diantaranya adalah penentuan spesifikasi secara detail, finalisasi antarmuka pengguna, pembuatan marker dan penentuan konten virtual untuk memenuhi kebutuhan sistem. Konten virtual yang diaugmentasikan ke dalam project berupa model 3 dimensi dan video animasi berisi penjelasan tentang klasifikasi hewan berdasarkan habitatnya. Prosedur dalam mengembangkan aplikasi berbasis Augmented Reality, dapat dijelaskan sebagai berikut:

1. Pembuatan marker

Pembuatan marker menggunakan software Photoshop dan untuk referensi marker diambil dari www.freepik.com. Berikut ini adalah daftar marker yang dibuat.

a. Marker menu Introduction dan contoh hewan Terrestrial 


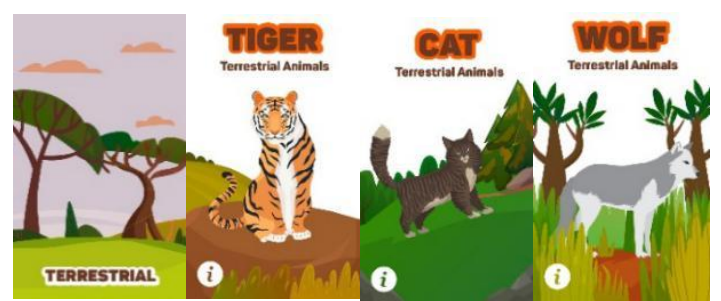

Gambar 6 Marker Menu Introduction dan Marker contoh hewan kelas ini[16][17][18]

b. Marker menu Introduction dan contoh hewan Aquatic

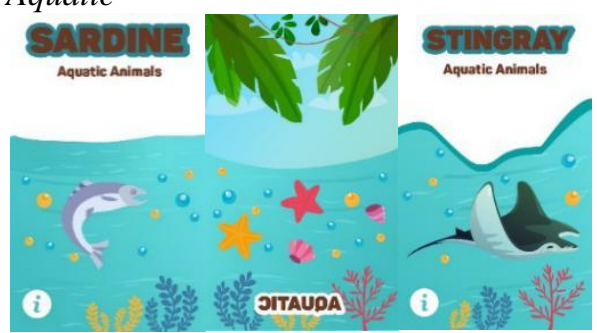

Gambar 7 Marker Menu Introduction Hewan Aquatic dan Contoh Hewan Kelas Ini [19][20]

c. Marker menu Introduction dan contoh hewan Amphibian

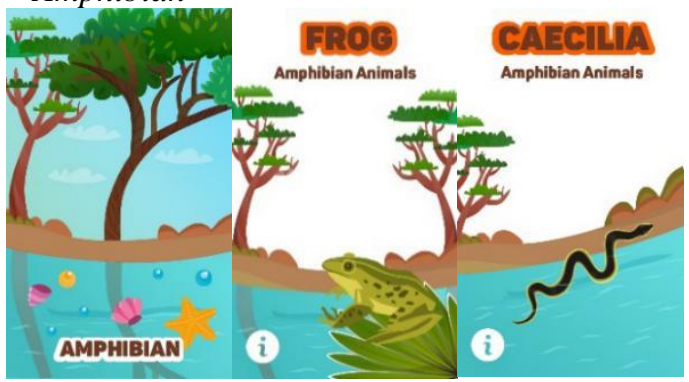

Gambar 8 Marker Menu Introduction Hewan Amphibian dan Contoh Hewan Kelas Ini [21][22]

Marker menu introduction hewan arboreal dan contoh hewan kelas ini

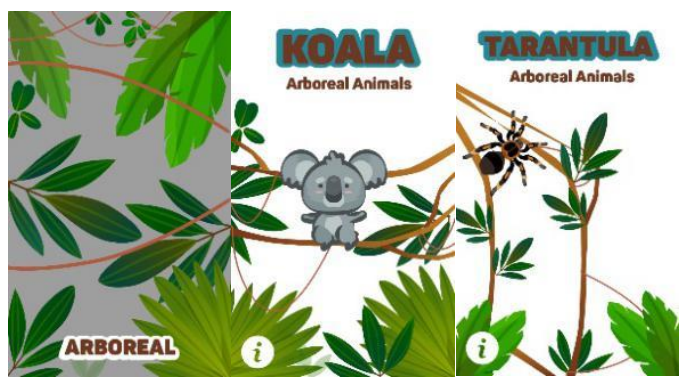

Gambar 9 Marker Menu Introduction Hewan Arboreal dan Contoh Hewan Kelas In
2. Menyiapkan konten AR

Konten AR yang disajikan berupa Objek 3D dan video penjelasan dari objek yang bersesuaian. Objek 3D diambil dari Unity Asset Store dan situs cadnav. Video animasi diambil dari national geographics.

3. Membuat lisensi, database dan gambar target dalam Vuforia

Unity sudah terintegrasi dengan Vuforia untuk pengembangan aplikasi Augmented Reality. Pada tahap ini, dibuat lisensi untuk aplikasi AR yang dibuat, kemudian pembuatan database dari marker yang sudah ditentukan.

4. Setting dan konfigurasi pada Unity untuk pembuatan AR dengan Vuforia

Di dalam projekUnity untuk Augmented Reality perlu diperhatikan untuk Build Setting, platform yang dipilih adalah android dan dalam player setting dipilih Vuforia Augmented Reality supported.

5. Menambahkan lisensi, database marker dari Vuforia ke dalam Unity

Database marker yang sudah dibuat dalam Vuforia diimpor ke dalam unity dan lisensi dari Vuforia dikopikan ke dalam unity.

6. Pemrograman aplikasi berbasis AR

Pembuatan scene menu utama, scene menu start popup untuk menu intruksi dan scripting untuk menjalankan fungsionalitas aplikasi. Pembuatan scene menu utama, scene menu start popup untuk menu intruksi dan scripting untuk menjalankan fungsionalitas aplikasi. Pada tahapan desain, telah dibuat marker untuk aplikasi Augmented Reality.

a. Implementasi scene menu utama

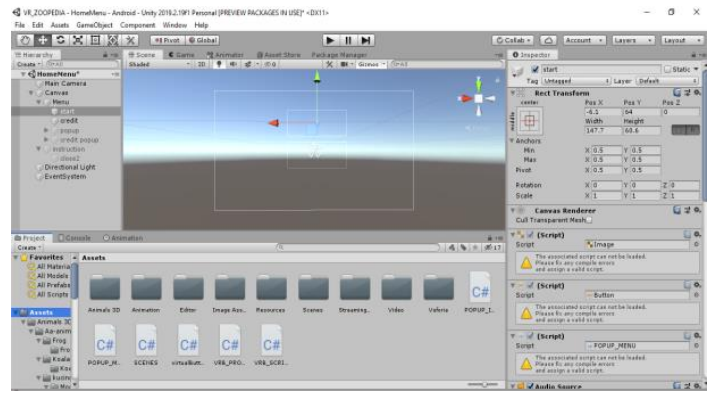

Gambar 10 Implementasi Scene Menu Utama 
b. Implementasi scene menu Introduction

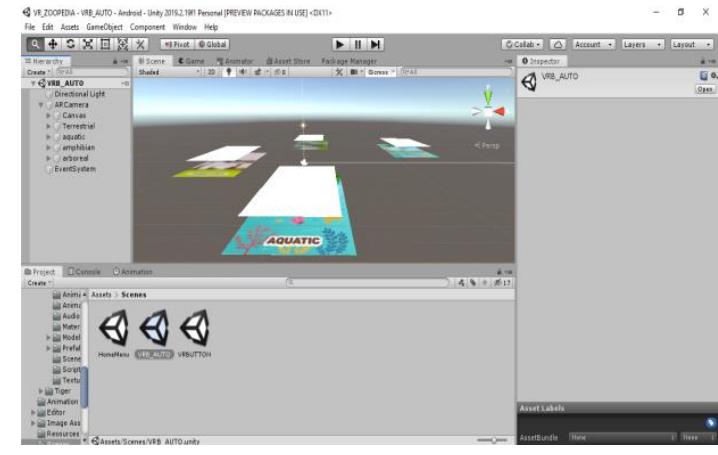

Gambar 11 Implementasi Scene Menu Introduction

c. Implementasi menu Scan Animal dapat dilihat pada Gambar 12.

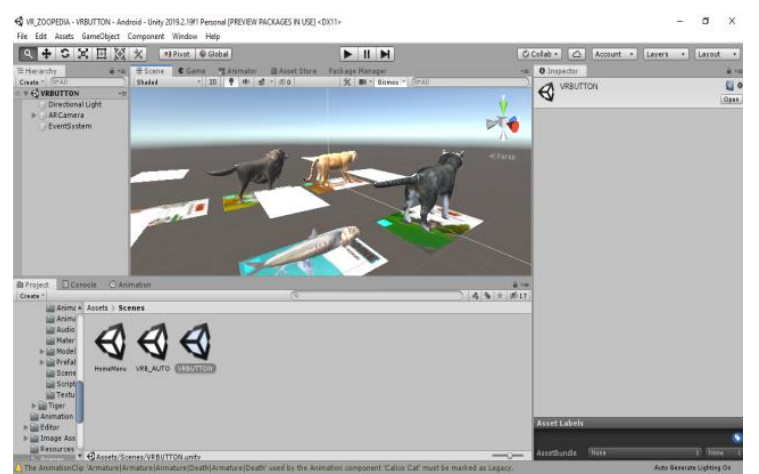

Gambar 12 Implementasi Scene Menu Scan Animals[23][24]

Pada tahapan desain, telah dibuat marker untuk aplikasi Augmented Reality. Marker yang dibuat yaitu marker untuk penjelasan klasifikasi hewan berdasarkan habitatnya sebanyak 4 buah yaitu marker untuk penjelasan hewan terrestrial, hewan aquatic, hewan amphibian dan hewan arboreal. Dari masing-masing kategori tersebut disajikan sebanyak 9 marker untuk pengenalan hewan, yaitu tiga marker untuk contoh hewan terrestrial, dua marker untuk contoh hewan Aquatic, dua marker untuk contoh hewan amphibian dan dua marker untuk contoh hewan arboreal.

7. Build aplikasi ke dalam bentuk instalasi android Projek yang sudah dibuat kemudian dibuild pada menu Build setting untuk platform android. Aplikasi media pembelajaran digital yang dikembangkan bernama ZooEduca dengan ekstensi.apk.

\section{Pengujian}

Pengujian dilakukan untuk melakukan verifikasi dan validasi. Metode pengujian yang digunakan adalah metode black box testing dan alpha testing. Tujuan penggunaan metode black box testing adalah untuk mengetahui bahwa fungsionalitas aplikasi sudah berjalan dengan benar sesuai perancangan. Alpha testing digunakan untuk menguji aplikasi kepada ahli materi dan ahli media. Ahli materi dalam aplikasi ini adalah guru IPA Sekolah Dasar. Dengan segala keterbatasan yang dimiliki, validasi dilakukan di SDIT Alhikmah di Tangerang Selatan. Ahli media yang dimaksud dalam penelitian ini adalah dosen ataupun praktisi yang memiliki kompetensi desain dan multimedia Augmented Reality. Verifikasi dan validasi dilakukan dengan cara membuat daftar pernyataan wawancara dan kuesioner, kemudian membagikannya kepada ahli materi dan ahli smedia. Setelah melakukan uji coba, maka para ahli materi dan media mengisi kuesioner tersebut.

\section{E. Daftar Pernyataan Wawancara Kepada Ahli Materi}

TABEL I. WAWANCARA UJI COBA APLIKASI ASPEK MATERI PEMBELAJARAN

\begin{tabular}{|c|c|c|}
\hline No & Pernyataan & Tanggapan \\
\hline 1 & $\begin{array}{l}\text { Materi pada aplikasi ini sesuai dengan } \\
\text { kurikulum }\end{array}$ & \\
\hline 2 & $\begin{array}{l}\text { Materi pada aplikasi ini disajikan } \\
\text { dengan menarik dan interaktif }\end{array}$ & \\
\hline 3 & $\begin{array}{l}\text { Aplikasi dapat membantu siswa belajar } \\
\text { tentang klasifikasi hewan berdasarkan } \\
\text { habitatnya }\end{array}$ & \\
\hline 4 & $\begin{array}{l}\text { Aplikasi dapat meningkatkan minat } \\
\text { siswa untuk belajar }\end{array}$ & \\
\hline 5 & $\begin{array}{l}\text { Materi pada Aplikasi ini dapat } \\
\text { digunakan bukan hanya untuk } \\
\text { pembelajaran di dalam kelas tetapi juga } \\
\text { dapat digunakan oleh masyarakat umum }\end{array}$ & \\
\hline 6 & $\begin{array}{l}\text { Media pembelajaran Digital yang } \\
\text { menggunakan marker untuk } \\
\text { menampilkan video pembelajaran lebih } \\
\text { menarik dan interaktif dibandingkan } \\
\text { dengan menonton video tersebut secara } \\
\text { langsung }\end{array}$ & \\
\hline 7 & $\begin{array}{l}\text { Aplikasi ini layak digunakan sebagai } \\
\text { media pembelajaran digital mengenal } \\
\text { klasifikasi hewan berdasarkan } \\
\text { habitatnya }\end{array}$ & \\
\hline
\end{tabular}

\section{F. Kuesioner}

Pertanyaan pada pengujian alpha untuk ahli media yang terdiri dari desain dan multimedia Augmented Reality. 
TABEL II. KUESIONER UJI COBA ALPHA ASPEK DESAIN ANTAR MUKA

\begin{tabular}{|c|c|c|c|c|c|c|}
\hline \multirow[t]{2}{*}{ No } & \multirow[t]{2}{*}{ Pernyataan } & \multicolumn{5}{|c|}{ Tanggapan } \\
\hline & & SS & $\mathbf{S}$ & $\mathbf{R}$ & TS & STS \\
\hline 1 & $\begin{array}{l}\text { Aplikasi memiliki } \\
\text { desain antar muka } \\
\text { yang baik dan } \\
\text { menarik }\end{array}$ & & & & & \\
\hline 2 & $\begin{array}{l}\text { Warna yang } \\
\text { digunakan pada } \\
\text { Aplikasi baik dan } \\
\text { menarik }\end{array}$ & & & & & \\
\hline 3 & $\begin{array}{l}\text { Menu pada aplikasi } \\
\text { jelas dan tidak } \\
\text { membingungkan }\end{array}$ & & & & & \\
\hline 4 & $\begin{array}{l}\text { Aplikasi dapat } \\
\text { dengan mudah } \\
\text { dipelajari dan } \\
\text { digunakan }\end{array}$ & & & & & \\
\hline 5 & $\begin{array}{l}\text { Semua Menu pada } \\
\text { aplikasi berguna dan } \\
\text { dapat berfungsi } \\
\text { dengan baik }\end{array}$ & & & & & \\
\hline 6 & $\begin{array}{l}\text { Nama aplikasi } \\
\text { mudah diingat }\end{array}$ & & & & & \\
\hline 7 & $\begin{array}{l}\text { Aplikasi sangat } \\
\text { berguna dalam } \\
\text { pembelajaran }\end{array}$ & & & & & \\
\hline
\end{tabular}

TABEL III. KUESIONER UJI COBA ASPEK MULTIMEDIA AUGMENTED REALITY

\begin{tabular}{|c|c|c|c|c|c|c|}
\hline \multirow[t]{2}{*}{ No } & \multirow[t]{2}{*}{ Pernyataan } & \multicolumn{5}{|c|}{ Tanggapan } \\
\hline & & SS & $\mathbf{S}$ & $\mathbf{R}$ & TS & STS \\
\hline 1 & $\begin{array}{l}\text { Sound pada aplikasi } \\
\text { terdengar dengan } \\
\text { baik }\end{array}$ & & & & & \\
\hline 2 & $\begin{array}{l}\text { Teks pada aplikasi } \\
\text { terbaca dengan } \\
\text { mudah }\end{array}$ & & & & & \\
\hline 3 & $\begin{array}{l}\text { Intruksi pada } \\
\text { aplikasi mudah } \\
\text { difahami }\end{array}$ & & & & & \\
\hline 4 & $\begin{array}{l}\text { Marker dapat } \\
\text { dideteksi dengan } \\
\text { mudah }\end{array}$ & & & & & \\
\hline 5 & $\begin{array}{l}\text { Video yang } \\
\text { disajikan sebagai } \\
\text { Augmented Reality } \\
\text { dapat didengar, } \\
\text { dilihat dengan jelas }\end{array}$ & & & & & \\
\hline 6 & $\begin{array}{l}\text { Virtual Button } \\
\text { membuat aplikasi } \\
\text { lebih interaktif }\end{array}$ & & & & & \\
\hline
\end{tabular}

\section{G. Teknik Analisis Data Hasil Kuesioner}

Kuesioner merupakan data kualitatif oleh karena itu pengolahan data kuesioner menggunakan teknik analisis data kulitatif. Teknik analisis data yang digunakan adalah analisis data model Miles dan Huberman [25]. Teknik analisis data yang digunakan dalam penelitian ini adalah sebagai berikut:
1. Analisis skala likert

Penyajian data skala likert dalam penelitian ini adalah sebagai berikut:

TABEL IV. PENYAJIAN DATA SKALA LIKERT

\begin{tabular}{|l|l|l|l|}
\hline No & Simbol & \multicolumn{1}{|c|}{ Kategori } & \multicolumn{1}{|c|}{$\begin{array}{c}\text { Bobot } \\
\text { Nilai }\end{array}$} \\
\hline 1 & SS & Sangat Setuju & 5 \\
\hline 2 & S & Setuju & 4 \\
\hline 3 & R & Ragu - ragu & 3 \\
\hline 4 & TS & Tidak Setuju & 2 \\
\hline 5 & STS & Sangat Tidak Setuju & 1 \\
\hline
\end{tabular}

2. Setelah menentukan bobot nilai dari setiap kategori maka selanjutnya adalah menentukan skor total tiap kategori dengan menggunakan rumus (1).

$$
\mathrm{S}_{\mathrm{k}}=\mathrm{B}_{\mathrm{n}} * \mathrm{~J}_{\mathrm{r}}
$$

Keterangan:

$$
\begin{aligned}
& \mathrm{S}_{\mathrm{k}} \quad=\quad \text { Skor total tiap kategori } \\
& \mathrm{B}_{\mathrm{n}} \quad=\quad \text { Bobot nilai kategori } \\
& \mathrm{J}_{\mathrm{r}} \quad=\text { Jumlah responden } \\
& \text { pemilih kategori } \\
& \text { tersebut }
\end{aligned}
$$

Skor total tiap kategori bergantung pada jumlah responden yang memilih kategori tersebut. Dari tahap ini akan diketahui skor total untuk kategori sangat setuju, setuju, ragu-ragu, tidak setuju dan sangat tidak setuju.

3. Menghitung skor total dari setiap pernyataan. Skor total dari setiap pernyataan merupakan hasil penjumlahan skor total kategori sangat setuju, skor total kategori setuju, skor total kategori raguragu, skor total kategori tidak setuju dan skor total kategori sangat tidak setuju. Secara matematis dapat dilihat pada formula (2).

$$
\mathrm{S}_{\mathrm{P}}=\sum_{k=1}^{5} S k
$$

Keterangan:

$\begin{array}{ll}\mathrm{S}_{\mathrm{P}} & =\text { Skor pernyataan } \\ \mathrm{S}_{\mathrm{k}} & =\text { Skor total tiap kategori } \\ \mathrm{k} & =\text { Kategori }\end{array}$

4. Menentukan kecenderungan jawaban responden dari masing masing aspek penilaian yaitu dari aspek desain dan multimedia Augmented Reality. Formula (3).

$$
\mathrm{S}_{\mathrm{A}}=\frac{\sum_{p=1}^{n} \mathrm{Sp}}{n}
$$


Keterangan:

$$
\begin{array}{lll}
\mathrm{S}_{\mathrm{A}} & = & \text { Skor total pernyataan } \\
& \text { pada aspek yang dinilai } \\
\mathrm{S}_{\mathrm{P}} & = & \text { Skor pernyataan } \\
\mathrm{p} & = & \text { Urutan pernyataan } \\
\mathrm{n} & = & \text { Jumlah pernyataan yang } \\
& \text { ada pada aspek yang } \\
& \text { dinilai }
\end{array}
$$

5. Penarikan kesimpulan

Pada tahap ini akan diperoleh kesimpulan sesuai dengan data yang telah dianalisis. Adapun acuan penilaian yang digunakan adalah sebagai berikut:

TABEL V. PENARIKAN KESIMPULAN

\begin{tabular}{|l|l|l|}
\hline No & Kategori & Rentang Nilai \\
\hline 1 & Sangat baik & $\operatorname{Tr} * 4<\mathrm{S}_{\mathrm{A}}<=\operatorname{Tr} * 5$ \\
\hline 2 & Baik & $\operatorname{Tr} * 3<\mathrm{S}_{\mathrm{A}}<=\operatorname{Tr} * 4$ \\
\hline 3 & Cukup baik & $\operatorname{Tr} * 2<\mathrm{S}_{\mathrm{A}}<=\operatorname{Tr} * 3$ \\
\hline 4 & Kurang baik & $\operatorname{Tr} * 1<\mathrm{S}_{\mathrm{A}}<=\operatorname{Tr} * 2$ \\
\hline 5 & Sangat kurang baik & $00,0<\mathrm{S}_{\mathrm{A}}<=\operatorname{Tr} * 1$ \\
\hline
\end{tabular}

Kemudian, dihitung persentase keberhasilan dari pembuatan media pembelajaran digital ini dengan menggunakan formula sebagai berikut:

$$
\mathrm{P}_{\mathrm{B}}=\frac{S_{A}}{T r * 5} * 100 \%
$$

Keterangan:

$$
\begin{aligned}
& \mathrm{P}_{\mathrm{B}} \quad=\text { Persentase Keberhasilan } \\
& \operatorname{Tr}=\text { Total Responden dalam } \\
& \text { uji coba penelitian } \\
& S_{A} \quad=\text { Skor total pernyataan } \\
& \text { pada aspek yang dinilai }
\end{aligned}
$$

\section{HASIL DAN PEMBAHASAN}

A. Hasil

Era industri 4.0 menjadikan teknologi menyatu dalam kehidupan manusia. Hampir semua bidang terintegrasi dengan teknologi informasi dan komunikasi. Salah satu implikasinya dalam bidang pendidikan dan pembelajaran. Media pembelajaran yang sangat berkembang saat ini yaitu media pembelajaran digital. Media pembelajaran digital ini membantu guru dan siswa dalam melaksanakan pembelajaran secara menarik dan interaktif.

Setelah melakukan pengembangan aplikasi media pembelajaran digital berbasis Augmented Reality didapatkan hasil sebagai berikut:

\section{User Interface}

a. Menu Utama

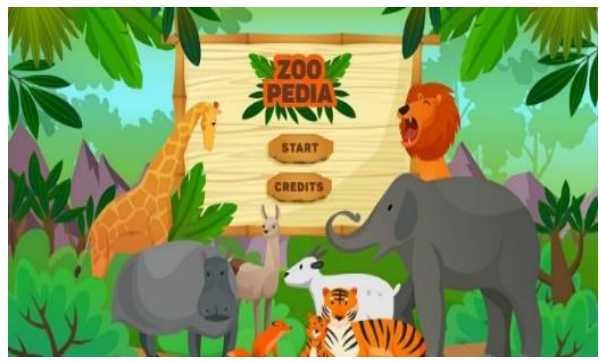

Gambar 13 UI Menu Utama [26]

b. Menu Mulai

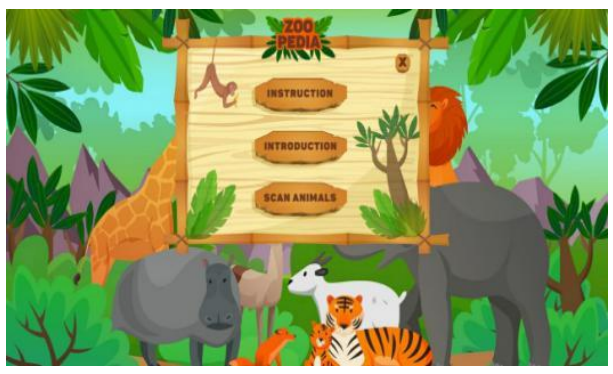

Gambar 14 UI Menu Mulai

c. Menu Instruksi

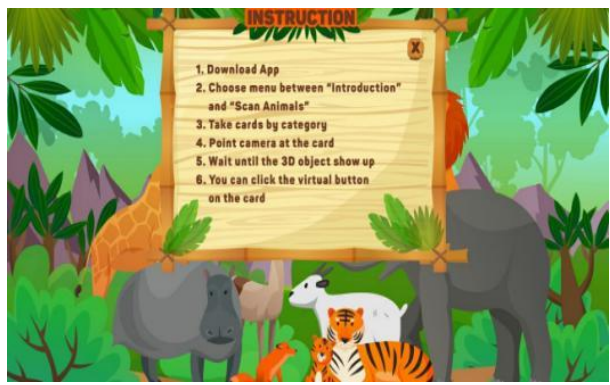

Gambar 15 UI Menu Intruksi

2. Scene Menu Introduction

TABEL VI. TAMPILAN MENU INTRODUCTION [27]

\begin{tabular}{|c|c|}
\hline \multicolumn{2}{|c|}{ Menu Introduction } \\
\hline $\begin{array}{c}\text { Marker } \\
\text { Hewan } \\
\text { Amphibian }\end{array}$ & Hasil Scan AR \\
\hline & \\
\hline & \\
\hline
\end{tabular}




\section{Scene Menu Scan Animals}

TABEL VII. IMPLEMENTASI MENU SCAN ANIMALS [28]

\begin{tabular}{|c|c|c|}
\hline \multicolumn{3}{|c|}{ Implementasi Menu Scan Animals } \\
\hline $\begin{array}{c}\text { Marker Contoh } \\
\text { Hewan } \\
\text { Amphibian } \\
\text { "Frog" }\end{array}$ & Hasil Scan AR \\
\hline FRog & \\
\hline
\end{tabular}

\section{B. Pengujian}

Pengujian fungsionalitas aplikasi yang digunakan adalah metode black box testing .

1. Uji coba fungsionalitas aplikasi menggunakan metode black box testing

a. Pengujian Menu Utama

TABEL VIII. UJI COBA BLACK BOX MENU UTAMA

\begin{tabular}{|l|l|l|l|}
\hline Input & Proses & Output & $\begin{array}{l}\text { Hasil } \\
\text { Pengujian }\end{array}$ \\
\hline $\begin{array}{l}\text { "Tombol } \\
\text { Start" }\end{array}$ & $\begin{array}{l}\text { Menampilkan } \\
\text { popup Menu } \\
\text { Utama }\end{array}$ & $\begin{array}{l}\text { Pop Up Menu } \\
\text { Utama }\end{array}$ & Sesuai \\
\hline $\begin{array}{l}\text { "Tombol } \\
\text { Credits" }\end{array}$ & $\begin{array}{l}\text { Menampilkan } \\
\text { popup } \\
\text { Identitas } \\
\text { Pengembang }\end{array}$ & $\begin{array}{l}\text { Pop Up } \\
\text { Identitas } \\
\text { Pengembang }\end{array}$ & Sesuai \\
\hline $\begin{array}{l}\text { "Tombol } \\
\text { ns" }\end{array}$ & $\begin{array}{l}\text { Menampilkan } \\
\text { popup Petunjuk } \\
\text { Penggunaan } \\
\text { Aaplikasi } \\
\text { dalam bahasa } \\
\text { Inggris “ }\end{array}$ & $\begin{array}{l}\text { Pop Up } \\
\text { Petunjuk } \\
\text { Penggunaan } \\
\text { Aaplikasi dalam } \\
\text { bahasa Inggris } \\
\text { “ }\end{array}$ & Sesuai \\
\hline $\begin{array}{l}\text { "Tombol } \\
\text { ion" }\end{array}$ & $\begin{array}{l}\text { "Menampilkan } \\
\text { Scene } \text { baru } \\
\text { untuk } \\
\text { memindai } \\
\text { marker" }\end{array}$ & $\begin{array}{l}\text { "Scene baru } \\
\text { untukmemindai } \\
\text { marker yang } \\
\text { dilengkapi } \\
\text { dengan tombil } \\
\text { exit } \text { scene }\end{array}$ & Sesuai \\
\hline $\begin{array}{l}\text { "Tombol } \\
\text { Scan } \\
\text { Animals }\end{array}$ & $\begin{array}{l}\text { "Menampilkan } \\
\text { Scene } \text { baru } \\
\text { untuk } \\
\text { memindan } \\
\text { marker }\end{array}$ & $\begin{array}{l}\text { Scene baru } \\
\text { untuk } \\
\text { memindan } \\
\text { marker } \\
\text { dilengkapi }\end{array}$ & Sesuai \\
\hline
\end{tabular}

\begin{tabular}{|l|l|l|l|}
\hline Input & Proses & Output & $\begin{array}{l}\text { Hasil } \\
\text { Pengujian }\end{array}$ \\
\hline & $\begin{array}{l}\text { dilengkapi } \\
\text { dengan button } \\
\text { exit" }\end{array}$ & $\begin{array}{l}\text { dengan button } \\
\text { exit" }\end{array}$ & \\
\hline
\end{tabular}

b. Pengujian Menu Introduction

Secara keseluruhan hasil implementasi pada menu Introduction dapat dilihat pada Tabel IX.

TABEL IX. HASIL PENGUJIAN KESELURUHAN MENU INTRODUCTION

\begin{tabular}{|c|c|c|c|}
\hline Input & Proses & Output & $\begin{array}{c}\text { Hasil } \\
\text { pengujian }\end{array}$ \\
\hline $\begin{array}{c}\text { Marker } \\
\text { Terrestrial }\end{array}$ & $\begin{array}{l}\text { Menampilkan } \\
\text { konten } \\
\text { Augmented } \\
\text { Reality video } \\
\text { penjelasan } \\
\text { hewan terrestrial }\end{array}$ & $\begin{array}{l}\text { Augmented } \\
\text { Reality } \\
\text { video } \\
\text { penjelasan } \\
\text { hewan } \\
\text { tereestrial }\end{array}$ & Sesuai \\
\hline $\begin{array}{l}\text { Marker } \\
\text { Hewan } \\
\text { Aquatic }\end{array}$ & $\begin{array}{l}\text { Menampilkan } \\
\text { konten } \\
\text { Augmented } \\
\text { Reality video } \\
\text { penjelasan } \\
\text { hewan Aquatic }\end{array}$ & $\begin{array}{c}\text { Augmented } \\
\text { Reality } \\
\text { video } \\
\text { penjelasan } \\
\text { hewan } \\
\text { Aquatic } \\
\end{array}$ & Sesuai \\
\hline $\begin{array}{l}\text { Marker } \\
\text { Hewan } \\
\text { Amphibian }\end{array}$ & $\begin{array}{l}\text { Menampilkan } \\
\text { konten } \\
\text { Augmented } \\
\text { Reality video } \\
\text { penjelasan } \\
\text { hewan } \\
\text { Amphibian }\end{array}$ & $\begin{array}{c}\text { Augmented } \\
\text { Reality } \\
\text { video } \\
\text { penjelasan } \\
\text { hewan } \\
\text { Amphibian }\end{array}$ & Sesuai \\
\hline $\begin{array}{l}\text { Marker } \\
\text { Hewan } \\
\text { Arboreal }\end{array}$ & $\begin{array}{l}\text { Menampilkan } \\
\text { konten } \\
\text { Augmented } \\
\text { Reality video } \\
\text { penjelasan } \\
\text { hewan Arboreal }\end{array}$ & $\begin{array}{c}\text { Augmented } \\
\text { Reality } \\
\text { video } \\
\text { penjelasan } \\
\text { hewan } \\
\text { Arboreal }\end{array}$ & Sesuai \\
\hline
\end{tabular}

c. Pengujian Menu Scan Animals

Secara keseluruhan hasil implementasi pada menu Scan Animal sebagai berikut.

TABEL X. PENGUJIAN KESELURUHAN MENU SCAN ANIMALS

\begin{tabular}{|c|c|c|c|c|c|}
\hline \multicolumn{6}{|c|}{ Implementasi Menu Introduction } \\
\hline \multirow[t]{2}{*}{ Marker } & \multirow[t]{2}{*}{ Proses } & \multicolumn{3}{|c|}{ Hasil Scan AR } & \multirow[b]{2}{*}{$\begin{array}{c}\text { Hasil } \\
\text { Peng- } \\
\text { ujian }\end{array}$} \\
\hline & & $\begin{array}{l}\text { Mod } \\
\text { el 3D }\end{array}$ & $\begin{array}{l}\text { Virtual } \\
\text { Button }\end{array}$ & $\begin{array}{c}\text { Video } \\
\text { Audi } \\
\text { o } \\
\end{array}$ & \\
\hline Tiger & \multirow{5}{*}{$\begin{array}{l}\text { Menampil } \\
\text { kan } \\
\text { model } \\
\text { 3D, } \\
\text { Virtual } \\
\text { button } \\
\text { dan video }\end{array}$} & $\sqrt{ }$ & $\sqrt{ }$ & $\sqrt{ }$ & Sesuai \\
\hline Cat & & $\sqrt{ }$ & $\sqrt{ }$ & $\sqrt{ }$ & Sesuai \\
\hline Wolf & & $\sqrt{ }$ & $\sqrt{ }$ & $\sqrt{ }$ & Sesuai \\
\hline Sardine & & $\sqrt{ }$ & $\sqrt{ }$ & $\sqrt{ }$ & Sesuai \\
\hline Stingray & & $\sqrt{ }$ & $\sqrt{ }$ & $\sqrt{ }$ & Sesuai \\
\hline
\end{tabular}




\begin{tabular}{|c|c|c|c|c|c|}
\hline Frog & \multirow{4}{*}{$\begin{array}{l}\text { pembelaj } \\
\text { aran } \\
\text { sesuai } \\
\text { dengan } \\
\text { marker } \\
\text { yang } \\
\text { dipindai }\end{array}$} & $\sqrt{ }$ & $\sqrt{ }$ & $\sqrt{ }$ & Sesuai \\
\hline Caecilia & & $\sqrt{ }$ & $\sqrt{ }$ & $\sqrt{ }$ & Sesuai \\
\hline Koala & & $\sqrt{ }$ & $\sqrt{ }$ & $\sqrt{ }$ & Sesuai \\
\hline Tarantula & & $\sqrt{ }$ & $\sqrt{ }$ & $\sqrt{ }$ & Sesuai \\
\hline
\end{tabular}

2. Pengujian alpha

Pada pengujian ini dilakukan untuk verifikasi dan validasi oleh ahli media dan ahli materi.

a. Validasi ahli materi

Validasi ahli materi dilakukan oleh guru IPA SD IT Al-Hikmah Tangerang Selatan. Adapun penilaian dari ahli materi mencakup beberapa hal sebagai berikut.

TABEL XI. PENILAIAN DARI AHLI MATERI PEMBELAJARAN

\begin{tabular}{|l|l|l|}
\hline No & \multicolumn{1}{|c|}{ Pernyataan } & \multicolumn{1}{c|}{ Tanggapan } \\
\hline 1 & $\begin{array}{l}\text { Materi pada aplikasi ini sesuai } \\
\text { dengan kurikulum }\end{array}$ & Sangat Setuju \\
\hline 2 & $\begin{array}{l}\text { Materi pada aplikasi ini disajikan } \\
\text { dengan menarik dan interaktif }\end{array}$ & Setuju \\
\hline 3 & $\begin{array}{l}\text { Aplikasi dapat membantu siswa } \\
\text { belajar tentang klasifikasi hewan } \\
\text { berdasarkan habitatnya }\end{array}$ & Setuju \\
\hline 4 & $\begin{array}{l}\text { Aplikasi dapat meningkatkan } \\
\text { minat siswa untuk belajar }\end{array}$ & Setuju \\
\hline 5 & $\begin{array}{l}\text { Materi pada Aplikasi ini dapat } \\
\text { digunakan bukan hanya untuk } \\
\text { pembelajaran di dalam kelas } \\
\text { tetapi juga dapat digunakan oleh } \\
\text { masyarakat umum }\end{array}$ & Setuju \\
\hline 6 & $\begin{array}{l}\text { Media pembelajaran Digital yang } \\
\text { menggunakan marker untuk } \\
\text { menampilkan video pembelajaran } \\
\text { lebih menarik dan interaktif } \\
\text { dibandingkan dengan menonton } \\
\text { video tersebut secara langsung }\end{array}$ & Setuju \\
\hline 7 & $\begin{array}{l}\text { Aplikasi ini layak digunakan } \\
\text { sebagai media pembelajaran } \\
\text { digital mengenal klasifikasi } \\
\text { hewan berdasarkan habitatnya }\end{array}$ & Sangat Setuju \\
\hline
\end{tabular}

b. Validasi ahli media

Pengujian ini melibatkan 14 orang ahli yang berasal dari dosen jurusan desain dan praktisi media. Validasi ini mencakup aspek sebagai berikut:

1. Aspek desain
TABEL XII. PENILAIAN DARI ASPEK DESAIN ANTAR MUKA

\begin{tabular}{|c|c|c|c|c|c|c|}
\hline \multirow[t]{2}{*}{ No } & \multirow[t]{2}{*}{ Pernyataan } & \multicolumn{5}{|c|}{ Tanggapan } \\
\hline & & SS & $\mathbf{S}$ & $\mathbf{R}$ & TS & STS \\
\hline 1 & $\begin{array}{l}\text { Aplikasi memiliki desain } \\
\text { antar muka yang baik dan } \\
\text { menarik }\end{array}$ & 13 & 1 & & & \\
\hline 2 & $\begin{array}{l}\text { Warna yang digunakan } \\
\text { pada Aplikasi baik dan } \\
\text { menarik }\end{array}$ & 9 & 5 & & & \\
\hline 3 & $\begin{array}{l}\text { Menu pada aplikasi jelas } \\
\text { dan tidak } \\
\text { membingungkan }\end{array}$ & 6 & 8 & & & \\
\hline 4 & $\begin{array}{l}\text { Aplikasi dapat dengan } \\
\text { mudah dipelajari dan } \\
\text { digunakan }\end{array}$ & 6 & 7 & 1 & & \\
\hline 5 & $\begin{array}{l}\text { Semua Menu pada } \\
\text { aplikasi berguna dan } \\
\text { dapat berfungsi dengan } \\
\text { baik }\end{array}$ & 8 & 5 & & 1 & \\
\hline 6 & $\begin{array}{l}\text { Nama aplikasi mudah } \\
\text { diingat }\end{array}$ & 4 & 8 & 2 & & \\
\hline 7 & $\begin{array}{l}\text { Aplikasi sangat berguna } \\
\text { dalam pembelajaran }\end{array}$ & 10 & 4 & & & \\
\hline
\end{tabular}

\section{Aspek Multimedia Augmented Reality.}

TABEL XIII. PENILAIAN DARI ASPEK MULTIMEDIA AR

\begin{tabular}{|l|l|l|l|l|l|l|}
\hline \multirow{2}{*}{ No } & \multicolumn{1}{|c|}{ Pernyataan } & \multicolumn{5}{c|}{ Tanggapan } \\
\cline { 3 - 7 } & & SS & S & R & TS & STS \\
\hline 1 & $\begin{array}{l}\text { Sound pada aplikasi } \\
\text { terdengar dengan baik }\end{array}$ & 10 & 4 & & & \\
\hline 2 & $\begin{array}{l}\text { Teks pada aplikasi } \\
\text { terbaca dengan mudah }\end{array}$ & 7 & 7 & & & \\
\hline 3 & $\begin{array}{l}\text { Intruksi pada aplikasi } \\
\text { mudah difahami }\end{array}$ & 6 & 8 & & & \\
\hline 4 & $\begin{array}{l}\text { Marker dapat dideteksi } \\
\text { dengan mudah }\end{array}$ & 7 & 6 & & 1 & \\
\hline 5 & $\begin{array}{l}\text { Video yang disajikan } \\
\text { sebagai Augmented } \\
\text { Reality dapat didengar, } \\
\text { dilihat dengan jelas }\end{array}$ & 8 & 4 & 2 & & \\
\hline 6 & $\begin{array}{l}\text { Virtual Button membuat } \\
\text { aplikasi lebih interaktif }\end{array}$ & 5 & 7 & 2 & & \\
\hline
\end{tabular}

\section{a. Analisis Data Hasil Kuesioner}

Analisis data kuesioner dilakukan dengan melakukan perhitungan terhadap skor total setiap pernyataan berdasarkan skor yang diperoleh dari masing masing poin. Responden pengujian alpha ini sebanyak 14 orang berasal dari ahli desain dan multimedia Augmented Reality.

Dari 14 responden tersebut dibuat skor kriteria pengujian alpha sebagai berikut: 
TABEL XIV. SKOR KRITERIA PADA PENGUJIAN ALPHA

\begin{tabular}{|c|c|c|}
\hline No & Kategori & Rentang Nilai \\
\hline 1 & Sangat baik & $56,1-70,0$ \\
\hline 2 & Baik & $42,1-56,0$ \\
\hline 3 & Cukup baik & $28,1-42,0$ \\
\hline 4 & Kurang baik & $14,1-28,0$ \\
\hline 5 & Sangat kurang baik & $00,0-14,0$ \\
\hline
\end{tabular}

Dari kategori tersebut diperoleh skor masing masing pernyataan sebagai berikut:

a. Aspek Desain

TABEL XV. ANALISIS DATA KUESIONER ASPEK DESAIN

\begin{tabular}{|c|c|c|c|}
\hline No & Pernyataan & $\begin{array}{l}\text { Perolehan } \\
\text { Nilai }\end{array}$ & $\begin{array}{c}\text { Persentase } \\
\text { Keberhasilan }\end{array}$ \\
\hline 1 & $\begin{array}{l}\text { Aplikasi memiliki } \\
\text { desain antar muka } \\
\text { yang baik dan } \\
\text { menarik }\end{array}$ & 69 & $98,6 \%$ \\
\hline 2 & $\begin{array}{ll}\text { Warna yang } \\
\text { digunakan pada } \\
\text { Aplikasi baik dan } \\
\text { menarik }\end{array}$ & 65 & $92,9 \%$ \\
\hline 3 & $\begin{array}{l}\text { Menu pada } \\
\text { aplikasi jelas dan } \\
\text { tidak } \\
\text { membingungkan }\end{array}$ & 62 & $88,6 \%$ \\
\hline 4 & $\begin{array}{lr}\text { Aplikasi } & \text { dapat } \\
\text { dengan } & \text { mudah } \\
\text { dipelajari } & \text { dan } \\
\text { digunakan } & \\
\end{array}$ & 61 & $87,1 \%$ \\
\hline 5 & \begin{tabular}{lr}
\multicolumn{3}{l}{ Semua Menu pada } \\
aplikasi & berguna \\
dan & dapat \\
berfungsi & dengan \\
baik & \\
\end{tabular} & 62 & $88,6 \%$ \\
\hline 6 & $\begin{array}{l}\text { Nama aplikasi } \\
\text { mudah diingat }\end{array}$ & 58 & $82,9 \%$ \\
\hline 7 & $\begin{array}{ll}\text { Aplikasi sangat } \\
\text { berguna dalam } \\
\text { pembelajaran }\end{array}$ & 66 & $94,3 \%$ \\
\hline
\end{tabular}

Dari perolehan skor masing masing pernyataan, maka skor rata-rata persentase penilaian dari aspek desain adalah 63,28 dengan persentase keberhasilan $90,4 \%$. b. Analisis aspek multimedia Augmented Reality

TABEL XVI. KUESIONER UJI COBA APLIKASI ASPEK MULTIMEDIA AUGMENTED REALITY

\begin{tabular}{|l|l|l|l|}
\hline No & \multicolumn{1}{|c|}{ Pernyataan } & $\begin{array}{c}\text { Perolehan } \\
\text { nilai }\end{array}$ & $\begin{array}{c}\text { Persentase } \\
\text { keberhasilan }\end{array}$ \\
\hline 1 & $\begin{array}{l}\text { Sound pada aplikasi } \\
\text { terdengar dengan baik }\end{array}$ & 66 & $94,3 \%$ \\
\hline 2 & $\begin{array}{l}\text { Teks pada aplikasi } \\
\text { terbaca dengan mudah }\end{array}$ & 63 & $90,0 \%$ \\
\hline 3 & $\begin{array}{l}\text { Intruksi pada aplikasi } \\
\text { mudah difahami }\end{array}$ & 62 & $88,6 \%$ \\
\hline 4 & $\begin{array}{l}\text { Marker dapat dideteksi } \\
\text { dengan mudah }\end{array}$ & 64 & $91,4 \%$ \\
\hline 6 & $\begin{array}{l}\text { Video yang disajikan } \\
\text { sebagai Augmented } \\
\text { Reality dapat didengar, } \\
\text { dilihat dengan jelas }\end{array}$ & 62 & $88,6 \%$ \\
\hline $\begin{array}{l}\text { Virtual Button } \\
\text { membuat aplikasi lebih } \\
\text { interaktif }\end{array}$ & 59 & $84,3 \%$ \\
\hline
\end{tabular}

Dari perolehan skor msing masing pernyataan diperoleh skor rata-rata untuk aspek multimedia Augmented Reality adalah 62,7 dengan persentase keberhasilan $89,6 \%$.

\section{KESIMPULAN DAN SARAN}

\section{A. Kesimpulan}

Media pembelajaran digital sebagai salah satu jenis media yang dapat digunakan untuk membantu menyukseskan ketercapaian dari capaian pembelajaran. Salah satu media digital yang sedang berkembang adalah media pembelajaran digital berbasis Augmented Reality. Di dalam membangun aplikasi berbasis Augmented Reality terdapat banyak software yang dapat digunakan diantaranya adalah Unity3D dan Vuforia. Pada penelitian ini telah berhasil menambahkan video sebagai salah satu konten virtual yang disajikan dalam Augmented Reality. Virtual button ditambahkan untuk membuat media ini menjadi lebih interaktif. Dengan ditambahkannya virtual button diharapkan pengguna lebih tertantang dan fokus dalam penggunaan media pembelajaran ini.

Pengujian black box digunakan untuk menguji fungsionalitas aplikasi. Hasil pengujian black box menunjukkan bahwa semua fungsionalitas pada aplikasi telah berjalan dengan baik sesuai dengan perencanaan dan perancangan. Aplikasi pembelajaran ini juga dapat dikembangkan sesuai dengan kebutuhan pengembangan untuk mendukung pembelajaran IPA di Sekolah Dasar.

Hasil pengujian alpha dari ahli materi pada aspek konten pembelajaran menunjukkan bahwa 
aplikasi ini sudah layak digunakan sebagai media pembelajaran di dalam kelas dan juga dapat digunakan sebagai media pembelajaran digital diluar kelas.

1. Hasil pengujian alpha pada aspek desain memperoleh skor 63,28 dengan persentase keberhasilan sebesar 90,4\%. Hasil tersebut menunnjukkan bahwa aplikasi memiliki desain yang baik dan sudah layak untuk didistribusikan kepada target audien.

2. Hasil pengujian alpha pada aspek multimedia Augmented Reality memperoleh skor 62,7 dengan persentase keberhasilan sebesar 89,6 \%. Hasil tersebut menunjukkan bahwa aplikasi pembelajaran ini memenuhi kriteria aplikasi multimedia berbasis Augmented Reality.

\section{B. Saran}

Penulis menyadari bahwa masih banyak kekurangan dalam pengembangan aplikasi media pembelajaran digital berbasis Augmented Reality ini. Setelah melakukan serangkaian proses pada penelitian ini, maka saran dari penulis adalah sebagai berikut:

1. Penggunaan marker dengan menggunakan metode markerless sangat layak dicoba untuk meningkatkan pengalaman dan kegunaan dari aplikasi berbasis AR.

2. Penggunaan virtual button sangat bermanfaat dan membuat aplikasi menjadi lebih interaktif, tetapi sangat perlu diperhatikan sensitifitas dari virtual button yang digunakan supaya dapat memberikan respon sebagai mana mestinya.

3. Aplikasi ini dapat dikembangkan sesuai dengan kebutuhan pada proses pembelajaran, misalkan dengan menambahkan mini game sebagai evaluasi dari konten pembelajaran yang diangkat dalam aplikasi ini.

\section{REFERENSI}

[1] Ibda, F. Perkembangan Kognitif: Teori Jean Piaget. Intelektualita. 2015; 3(1): 27-37.

[2] Savitri N, Aris [1]M, W., Supia [1]nto A, A. Augmented Reality Application for Science Education on Animal Classification. International Conference on Sustainable Information Engineering and Technology (SIET). Lombok. 2019; pp: 270-275.

[3] Zarzuela M, M. et all. Mobile Serious Game using Augmented Reality for Supporting Children's Learning about Animals. 2013 International Conference on Virtual and Augmented Reality in Education. Spain. 2013; $25: 375-381$.

[4] Tsai C. S, Yen J. C. The Augmented Reality Application of Multimedia Technology in Aquatic Organisms Instruction. Journal of Software Engineering and Applications. 2014; 07(09):745-755.
[5] Rokiyah, I \& Budiastra, K. Modul 1 Teori Belajar dalam Pembelajaran IPA SD. 2014. [Online]. Tersedia: http://repository.ut.ac.id/4021/2/PDGK4202-M1.pdf. [Diakses: 16 April 2020].

[6] Juwantara, R. A. Analisis Teori Perkembangan Kognitif Piaget Pada Tahap Anak Operasional Konkret 7-12 Tahun Dalam Pembelajaran Matematika. AlAdzka: Jurnal Ilmiah Pendidikan Guru Madrasah Ibtidaiyah. 2019; 9(1): 27 - 34 .

[7] Kamus Besar Bahasa Indonesia. [Online] Tersedia di https://kbbi.kemdikbud.go.id/entri/media

[8] Arsyad, A. Media Pembelajaran. Jakarta: PT Raja Grafindo Persada. 2011.

[9] Munir, PEMBELAJARAN DIGITAL. 2017. Bandung : Alfabeta.

[10] Kiryakova, G dkk. The Potential of Augmented Reality to Transform Education Into Smart Education. TEM Journal. 2018; 7(3):556-565.

[11] Kroll, M. What is AR? (Augmented Reality). 2016, extension, 13 Juni 2016, [Online]. Tersedia: https://impact.extension.org/2016/06/what-is-araugmented-reality/. [Diakses: 15 April 2020].

[12] Barjtaya S, Sharma A, Rani U. A detailed study of Software Development Life Cycle (SDLC) Models. International Journal Of Engineering And Computer Science. 2017; 6(7): 22097-22100.

[13] Patil, P. P, \& Alvares, R. Cross-platform Application Development using Unity Game Engine. International Journal of Advance Research in Computer Science and Management Studies. 2015; 3(4): 19-27.

[14] Getting Started with Vuforia Engine in Unity Library.fuvoria.com. Tersedia: https://library.Vuforia.com/articles/ Training/gettingstarted-with-Vuforia-in-unity.html. [Diakses: 15 April 2020]

[15] Kemendikbud. KURIKULUM 2013 KOMPETENSI DASAR Sekolah Dasar (SD)/ Madrasah Ibtidaiyah (MI). 2013. Kemendikbud: Jakarta.

[16] Collection of hand drawn tigers Free Vector. 2019. freepik.com. [Online]. Tersedia https://www.freepik.com/free-vector/collection-handdrawn-tigers_4850703.htm. [Diakses: 17 April 2020].

[17] Domestic cat breeds flat icons collection Free Vector. 2018. freepik.com. [Online]. Tersedia : https://www.freepik.com/free-vector/domestic-catbreeds-flat-icons-collection_3796746.htm. [Diakses: 17 April 2020].

[18] Forest animals set in realistic style Free Vector. 2016. freepik.com. [Online]. Tersedia : https://www.freepik.com/free-vector/forest-animalsset-realistic-style_940201.htm. [Diakses: 17 April 2020].

[19] Ocean underwater animals cartoon retro characters set with stingray shark turtle swordfish Free Vector. 2018. freepik.com. [Online]. https://www.freepik.com/freevector/ocean-underwater-animals-cartoon-retrocharacters-set-with-stingray-shark-turtleswordfish_3791455.htm. [Diakses: 17 April 2020].

[20] Sea food icon flat set Free Vector. 2019. Freepik.com. Tersedia: https://www.freepik.com/free-vector/seafood-icon-flat-set_3947954.htm. [Diakses: 17 April 2020].

[21] Venomous snakes cartoon set Free Vector. 2019. freepik.com. Tersedia: https://www.freepik.com/freevector/venomous-snakes-cartoon-set_5971414.htm. [Diakses: 17 April 2020]. 
[22] Reptiles and amphibians set Free Vector. 2019. freepik.com. Tersedia: https://www.freepik.com/freevector/reptiles-amphibians-set_4425937.htm.

[Diakses: 17 April 2020].

[23] White Tiger 3D Model. 2019. free3D.com. Tersedia: https://free3d.com/3d-models/tiger. [Diakses: 18 April 2020].

[24] Wolf Rigged And Game Ready 3D Model. 2020. free3D.com. Tersedia: https://free3d.com/3dmodel/wolf-rigged-and-game-ready-42808.html.

[Diakses: 18 April 2020].

[25] Ahyar H, dkk. Metode Penelitian Kualitatif dan Kuantitatif. Yogyakarta: CV. Pustaka Ilmu Grup Yogyakarta. 2020
[26] Welcome to zoo cartoon illustration Free Vector. 2019 freepik.com. Tersedia: https://www.freepik.com/freevector/welcome-zoo-cartoon-

illustration_6169813.htm. [Diakses: 18 April 2020].

[27] Learn about Amphibians, Amphibians Animal, Types of Amphibians. 2018. youtube.com. Tersedia: https://www.youtube.com/watch?v=MY3x_b8albM. [Diakses 19 April 2020]

[28] Bullfrogs Eat Everything National Geographic. 2019. youtube.com.

Tersedia: https://www.youtube.com/watch?v=vhywWia6II8. [Diakses 19 April 2020] 